\title{
Developing Co-management for Conservation and Local Development in China's National Parks: Findings from Focus Groups in the Sanjiangyuan Region
}

\section{Ting Ma}

Institute of Geographic Sciences and Natural Resources Research, Chinese Academy of Sciences https://orcid.org/0000-0002-1814-7997

\section{Brent Swallow}

University of Alberta https://orcid.org/0000-0003-3814-4838

\section{J. Marc Foggin}

University of British Columbia https://orcid.org/0000-0002-2663-6715

Linsheng Zhong ( $\square$ zhongls@igsnrr.ac.cn )

Institute of Geographic Sciences and Natural Resources Research, Chinese Academy of Sciences https://orcid.org/0000-0002-2298-0949

\section{Weiguo Sang ( $\square$ swg@muc.edu.cn )}

Minzu University of China https://orcid.org/0000-0002-7131-896X

\section{Research Article}

Keywords: Socio-ecological systems, environmental conservation, sustainable development, public policy, transformation, empowerment, communities, gender dimensions, focus groups, Sanjiangyuan National Park, Tibetan Plateau, China

Posted Date: November 19th, 2021

DOI: https://doi.org/10.21203/rs.3.rs-1089846/v1

License: (1) This work is licensed under a Creative Commons Attribution 4.0 International License. Read Full License 


\section{Abstract}

Environmental protection in China has progressed significantly in the past decades, including introduction of more collaborative approaches in the management of protected areas and the establishment of a new national park system. Many milestones have been achieved. While such developments are driven largely by national and global goals, the people who are most affected are those who reside in the protected landscapes. A range of strategies have been proposed and tried in relation to local development, with many important lessons learned, yet little has been heard to date directly from the community stakeholders themselves. In this study we report on feedback and recommendations received from focus groups in vicinity of China's first national park, Sanjiangyuan, regarding lived experiences of "community co-management" by Tibetan herders and local officials. Overall, the most recent National Park model is deemed successful, albeit with some notable perceived limitations. Focus group participants recommend more balanced compensation opportunities including for communities living outside but in close proximity to the paranagement and health care) and establishing a more effective compensation or insurance system to offset econok, eased restrictions on ecotourism, provision of public services for communities in the park (especially waste mmic losses due to wildlife damage.

\section{Introduction}

The need for sustainability is broadly agreed globally. On this basis, the Sustainable Development Goals (SDGs) have been adopted to help us collectively end poverty, protect the planet, and ensure prosperity for all (see UN Resolution 70/1, Transforming our world: the 2030 Agenda for Sustainable Development (United Nations General Assembly, 2015). These goals are ambitious, integrated and holistic, and virtually every government and stakeholder group recognize they must play their part, from high-level formal policies and legislation at international, national and sub-national levels to the grounded commitments and actions taken by the general public both privately and through civil society and the private sector (Bryan et al., 2018).

However, with increasing regional and international connectivity (cf. globalization), the approaches adopted and decisions made in one place also impact communities and situations elsewhere, often in ways well beyond the scope of the original intended areas or sectors of focus. Additionally, sustainabilityoriented goals alone rarely drive all decisions. Political, economic, and environmental factors bring tradeoffs such that, at best, we can hope for science-informed if not actually evidence-based decisions. Further, questions of 'who' should be involved in planning and decision-making (i.e., governance) are equally as important as the 'what' (i.e., the particular decisions made, e.g. management prescriptions) (Foggin, 2018). However, whatever the processes followed or challenges encountered, learning from experiences and channeling important lessons learned into future development programs and actions are of paramount value.

This paper seeks to contribute to the goal of further linking China and the rest of the world in matters of environmental management and conservation by analyzing recent experiences in China and making 
them more widely known outside the country, as well as connecting the reported experiences in China to global 'best practices' and simultaneously making these better known within the country. We give special attention to local reactions as elicited through focus groups and derive important lessons to help guide future programming. The Sanjiangyuan region, Qinghai Province, is offered as case study for listening and responding to local voices about how co-management has been practiced and how it has affected livelihoods, as well as local reported perceptions regarding environmental impacts of the national park. Overall, the results indicate that the benefits and challenges of this large social and ecological transformation project are unevenly distributed, with distinct impacts on those who live in the national park, those who live near the national park, and those who live downstream of the park. The results indicate that the national park is simultaneously generating meaningful improvements for the natural environment and for local people's livelihoods and socioeconomic development, but it is also found that the model could be adjusted and improved to further benefit residents inside and outside the park through fair and equitable transformations.

\section{Methods}

We used a mixed-method qualitative research design broadly used for critical policy analysis as applied in India by Breitkreuz et al. (2017) and described in greater detail by Breitkreuz and Swallow (2019). The first element of this approach was to review key documents describing the sustainable development and conservation policies and plans that China has implemented since 1994 at national level and in the Sanjiangyuan region, with special emphasis on Sanjiangyuan (Three Rivers' headwaters) National Park area. This helped us to better understand the evolving policy objectives as well as the local implementation of those policies. The second element centered on a series of contemporary focus group interviews designed to elicit the perspectives and experiences of the people in the local area who are most exposed to the impacts of the policies. This aligns with the tradition in critical ethnography that recognizes the best way to understand a social process is from the inside. While this approach does not allow us to isolate specific success indicators or cause-effect relationships, it does allow for the "subjective voice" of the end users - those who are most directly affected by the policies - as well as the views of local officials to provide critical insights into the local contexts and policy implementation in the focal areas. As described by Breitkreuz and Swallow (2019), this approach to critical policy analysis adds to the literature on multi-dimensional microanalysis (Novotn, Kubelková, \& Joseph, 2013) and the combination of methods allows us to understand how policies have been implemented in the local contexts and how they are affecting local people and local to regional development. Although the specific results of this study may not be generalizable to all China, we believe the insights gained will contribute to a deepened understanding of several key aspects of environmental policies affecting the Sanjiangyuan National Park, and may contribute to the review and possibly revision of the critical new directions and approaches in environmental conservation in China, particularly conceptual models highlighted in the launch of China's national park system ${ }^{[1]}$. 
We approached the policy review in three complementary ways, progressively moving toward a more complete understanding of the context operating in the Sanjianyuan area. The first approach was to review the international literature, primarily in English language, on the dynamics of social-ecological systems and co-management arrangements involving government and local communities, including indigenous communities. Our case study area is a traditional home of the Tibetan people who have relied on livestock grazing for much of their livelihood and who have a distinct culture, language, way of life, and sense of identity. The second approach was to review policy documents and proclamations of relevant government agencies at national level, by the Qinghai Provincial government, and the administration of Sanjiangyuan National Park itself. Most of those documents are only available in Chinese language. New developments over the last four years have been tracked in real time. The third approach was based on Chinese scholarly literature exploring the Chinese experience with environmental protection and ecological transformation. Our policy review - as presented here - iterated between these three different but complementary approaches.

Local perspectives on policies were generated through focus group interviews. A total of 12 focus group studies were conducted, with a total of 219 participants. We used focus groups because they are an effective way to collect a large amount of data on a particular issue, information that may be little known but, once highlighted, can be used to identify key topics for further exploration (Morgan, 1997). A pilot focus group was conducted in the Yellow River headwaters ${ }^{[2]}$ in July 2018 to explore the focus group members' concerns with the policies that had been implemented in the area and to determine whether the focus group method could be effective for collecting data for the project. Another 12 focus group studies were conducted in July 2020 at 4 sites. In each site, we convened three focus groups: one with only male residents, one with only female residents, and one with representatives of local government administrations and park management agencies. Participants in this study provided voluntary and written informed consent. Each focus group consisted of 5 to 20 participants, with an average of 12 participants. These groups lasted 90 to 120 minutes; due to the special situation of Covid-19, we could not provide refreshments to participants. The broad, open-ended questions that guided the focus group interviews and discussions are shown in Box 1, below.

Box 1 


\section{Questions for focus group survey}

a) Please describe the recent history of the national park.

b) What are the different ways in which people are affected by the park?

c) Who is most positively affected by the park in this area, and why?

d) Who is most negatively affected by the park in this area, and why?

e) What has been done, or may be done, to improve the situations of people who have been negatively affected?

Table 1. Research sites (Four geographic categories of focus groups $\times 3$ types of participants $=12$ focus groups)

\begin{tabular}{|c|c|c|}
\hline & Towns inside national park & $\begin{array}{l}\text { Towns outside national } \\
\text { park }\end{array}$ \\
\hline $\begin{array}{l}\text { Mekong River National Park (Zaduo } \\
\text { County) }\end{array}$ & $\begin{array}{l}\text { Zhaqing, Chadan } \\
\underline{\text { male, female, and gov/NP }}\end{array}$ & $\begin{array}{l}\text { Sulu, Jieduo, Sahuteng } \\
\underline{\text { male, female, and gov/NP }}\end{array}$ \\
\hline $\begin{array}{l}\text { Yellow River National Park (Maduo } \\
\text { County) }\end{array}$ & $\begin{array}{l}\text { Zhalinghu, Huanghe, } \\
\text { Machali } \\
\text { male, female, and gov/NP } \\
\text { FGs }\end{array}$ & $\begin{array}{l}\text { Huashixia } \\
\underline{\underline{\text { Fale }}}, \text { female, and gov/NP }\end{array}$ \\
\hline
\end{tabular}

${ }^{[1]}$ On October 12, 2021, at the 15th Conference of the Parties to the Convention on Biological Diversity, China officially established the first batch of national parks, they are Sanjiangyuan National Park, Giant Panda National Park, Siberian Tiger and Leopard National Park, Hainan Tropical Rain Forest National Park, Wuyi Mountain National Park. The protected area is 230,000 square kilometers, covering nearly $30 \%$ of the land area of wild animals and plants under national key protection (People's Daily, 2021).

${ }^{[2]}$ The Sanjiangyuan National Park (figure 2) has three main sections, the headwaters or source areas of the Yangtze (Changjiang) River, the Yellow (Huanghe) River, and the Mekong (Lancang) River. These three main sections of the Sanjiangyuan National Park are administered quasi-independently albeit in coordinated fashion. Additionally, in China, each of these three sections is often referred to as an independent national park, even though all three are technically part of the single larger, tripartite Sanjiangyuan National Park. 


\section{Background}

\subsection{Major Geographies}

The Qinghai-Tibet Plateau encompasses around one fourth of China's land area and provides many benefits, nationally and globally, especially in terms of the ecosystem services deriving from the headwaters of the many major Asian rivers originating on the plateau (Foggin 2016; Kreutzmann, 2016; Squires \& Lu, 2017). Around 3 billion people rely on the life-giving water resources of these great rivers and their watersheds. The Qinghai-Tibet Plateau itself is often called the 'third pole' of the world because of its extensive area and very high elevation (Tandong et al., 2012). Even more strikingly, the plateau's simple presence and its land cover (including annual snow cover) affect global climate systems, particularly through characteristics of the Asian monsoon (Yang et al., 2021; Ma et al., 2017; Yang et al., 2017). Ecologically, four main ecosystem types are identified: alpine meadows, alpine grasslands, alpine deserts, and alpine shrubs (Long et al., 2008). Together, these vegetative communities provide the basis for pastoralist livelihoods that developed over millennia (Foggin, 2021). The Qinghai-Tibet plateau is thus a region populated not only by unique and diverse wildlife but also by Tibetan herders whose livestock have long provided for their necessities and well-being (Gruschke, 2012; Goldstein, 1969). Overall, the plateau constitutes one of the world's most extensive integrated socio-ecological systems (Cong et al., 2015).

The Sanjiangyuan area - that is, the headwaters areas of the Yangtze (Changjiang), Yellow (Huanghe) and Mekong (Lancangjiang) ${ }^{[3]}$ Rivers - is located in the heart of the Qinghai-Tibet Plateau (Yan, Li, Hua, Peng, \& Zhang, 2017; Foggin,2008; Shao et al., 2013). It covers an area of $363,000 \mathrm{~km}^{2}$, or about half of Qinghai Province (Du, 2012). Because of the great ecological significance of the area's biodiversity and its important water regulatory functions for the entire country and globally, around half of the Sanjiangyuan area $\left(153,000 \mathrm{~km}^{2}\right)$ was designated as a national nature reserve in 2000 (Sheehy, Miller, \& Johnson, 2006; Li et al., 2020), an area equivalent to England and Wales combined (Foggin, 2015). Most of this vast area $\left(123,100 \mathrm{~km}^{2}\right)$ was recently designated as a national park, the most recent step in a series of significant policy changes seeking to reverse decades of unsustainable development decisions and actions that have greatly degraded ecosystems including grasslands, lakes and glaciers throughout northwest China (Wu et al., 2020; Xinhua, 2017; Shang, 2019). The Sanjiangyuan National Park is comprised of three contiguous sections that encompass the headwaters of the Lancang in the south (adjacent to Tibet Autonomous Region), the Yangtze in the south-central part, and the Yellow to the north-east (see Figure 1).

In parallel with these institutional changes over the past 20 years, as in other areas of the plateau and more broadly across the high mountain regions of Central Asia, the Sanjiangyuan area and its inhabitants remain vulnerable to a wide range of environmental, economic and sociopolitical factors, many of which originate outside their geographical areas yet greatly impact the environment and people's lives and well-being. This is Globalisation 101, which operates in ways well beyond simple market integration. Environmental policies and climate change, for example, both affect mountain communities, 
the latter through shrinking glaciers and the changing seasonality and intensity of precipitation, thus impacting pastoralist livelihoods (Manandhar, Xenarios, Schmidt-Vogt, Hergarten, \& Foggin, 2017).

\subsection{Protected Areas in China}

China has had high ambitions for its protected areas, largely developed following the model of strict nature reserves. In fact, China has established a vast network of nature reserves since 1956, now with 2,729 nature reserves nationwide, covering about $15 \%$ of the country's territory. State-managed reserves cover two-thirds of this area (Cao et al.,2015; Guo \& Cui, 2015). More broadly, there are over 10,000 protected areas (including nature reserves) covering about $18 \%$ of the country's land area, including forests, geological parks, wetland parks, world natural and cultural heritage sites and scenic spots (China Global Television Network, 2017; Zhu, Cao, Huang, Xiao, \& Zhai, 2019).

One of the challenges inherent in nature reserves is to find ways to balance nature conservation with the needs and socio-economic aspirations of local communities (Cao et al., 2021). The national park model has therefore recently been introduced in China, seeking to redress previous imbalances by integrating human activities with the protection of special habitats and regulating services (Xu et al., 2017; Li, Wang, Axmacher, Zhang, \& Zhu, 2016). The official plan of the national park system clearly stipulates that "national parks will be established to ... combine ecological protection and sustainable development" and that the primary difference between nature reserves and national parks "is that the latter can provide more social and economic benefits.... Any successful conservation and use of national parks should maintain a balance, so that they can provide both development opportunities and effective protection" (He, M., \& Cliquet, A., 2020). The National Park system aims, further, to advance China's vision of

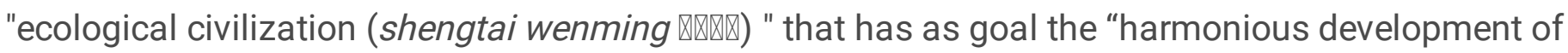
people, nature, and society" (Sheng et al., 2020). The same authors also note that the national park system could help resolve two outstanding challenges from the previous model, namely that "the economic prioritization over social and ecological considerations that causes massive ecological degradation, and the conflicting, overlapping, and inconsistent administrative and institutional structures that result in serious inefficiencies and conflicts" (Sheng et al. 2020).

Sanjiangyuan National Park is the first national park established in China, with two parallel goals: environment protection, and social and economic development of communities. The expected launch of the national park was in late 2020, but due to Covid-19 this has been postponed (Zhao, Liu, Dong, \& Shao, 2016; China Daily, 2020; Foggin and Yuan, 2020), and finally occurred on 12 October 2021 (People's Daily, 2021).

Initially, each section of the national park was sub-divided into a core conservation area (core zone) where no human activity can take place, ecological conservation and restoration areas (buffer zone) where limited human activity can take place, and areas where traditional forms of natural resource utilization such as pastoralism can still occur (with different priorities or limitations based on ecological characteristics). Later, the three areas were re-organized and simplified into first- and second-level functional zones. The primary functional zone applies strict protection, focusing on snow-capped 
mountains, glaciers, rivers, lakes, wetlands, grassland meadows and forest shrubs. First-level protection severely restricts human activities in order to conserve water, soil, biodiversity and pristine ecosystems. The secondary functional zone allows minimal activity by the local residents as well as approved scientific research, but otherwise promotes conservation of protected areas, special habitats, and natural conservation areas (Sanjiangyuan National Park, 2021). There are a total of 53 villages located within the Sanjiangyuan National Park.

\subsection{Evolving Policy Context}

In order to understand the background and evolving contexts of the Sanjiangyuan region in terms of socioeconomic systems and development paradigms, we reviewed 13 government development policies in China since 1994 with special reference to the Sanjiangyuan area as well as to pertinent environmental hazards (Table 1). This information mainly comes from the relevant websites of the Sanjiangyuan National Park, supplemented by academic literature. As seen in the Table 1, nature reserves are more exclusionary than national parks, thus the recent shift to a national park model better embraces comanagement as compared to stricter command-and-control approaches - also consistent with China's national ecological compensation policy (Hu et al, 2019) as well as further development and refining of the concept of Ecological Civilization (Kuhn, 2019; Maxwell et al., 2020). Ecological Civilization has been written into China's constitution as the ideological framework for the country's environmental policies, laws and education. It is also increasingly presented not only as a response to environmental degradation in China, but as a vision for our global future (Hansen et al, 2019).

In China and around the world, protected areas (or PAs) ${ }^{[4]}$ have been the most common tool used, in a formal sense, to promote nature conservation (Maxwell et al., 2020). Amongst protected areas in China, nature reserves continue to be the most common (Xu et al., 2017) even though they tend to separate people from nature, while national parks are still in preliminary experimental stages. Given the many known benefits of local-level engagement in PAs for both people and for nature, a critical question arises, how can more community-centered approaches in conservation be integrated into nationally-endorsed plans and approaches? Local communities remain the longest-standing custodians of the environment, and it is increasingly recognized that such communities are the best placed to contribute to broadly desired conservation outcomes (Sobrevila 2008). In light of this, a system of rangers or wardens from local communities has been trialed in the Sanjiangyuan area and now is integrated in the inaugural functioning of China's first national park (Foggin, 2018; Yan, 2019). The development of Sanjiangyuan National Park over its 5-year trial phase built on earlier experiences that were initiated under the nature reserve model, when community co-management approaches and other forms of positive engagement with local people first emerged. The "one village, one post" (yicun yidian) collaborative conservation project was launched in 2006 by the NGO Plateau Perspectives together with the nature reserve, and it developed over several years with Tibetan pastoralist communities. "One village, one post" was subsequently scaled-up in the UNDP GEF-supported Qinghai Biodiversity Conservation Project (2013-18). This larger project enabled the further strengthening of the earlier co-management venture, helping to embed community-centric approaches into protected area legislation and practice at the provincial level 
(Foggin, 2005; 2018). Since trial development of the Sanjiangyuan National Park began in 2015, implementation of the even finer-scale "one household, one post" policy increased the income of 17,211 herders, helping to gradually improve their living standards. These 'posts' are the equivalent of 'ranger stations' - but instead of being a government built and administered post, i.e. a physical building from which monitoring activities are carried out, so-called 'household posts' are the location of each and every household resident in the national park (or nature reserve, as the case may be). They are 'posts' in terms of their physical structure and location, and 'public' inasmuch as they are run by the public, i.e. overseen by a selected individual per household. As each household has someone paid by the national park to provide agreed services, each household thus is recognized as serving a function of ecological monitoring.

Table 2. Timeline of major environmental disasters and policy events that have affected China since 1994 


\begin{tabular}{|c|c|c|c|c|}
\hline Year & $\begin{array}{l}\text { Major } \\
\text { environmental } \\
\text { events in } \\
\text { China }\end{array}$ & $\begin{array}{l}\text { National policies } \\
\text { impacting the } \\
\text { Sanjiangyuan region }\end{array}$ & $\begin{array}{l}\text { Provincial policies for } \\
\text { Sanjiangyuan }\end{array}$ & Source \\
\hline 1994 & & $\begin{array}{l}\text { Three Gorges Project } \\
\text { (Sanxia gongcheng) } \\
\text { completed in 2017) }\end{array}$ & & $\begin{array}{l}\text { (Li et al., } \\
2020)\end{array}$ \\
\hline 1997 & $\begin{array}{l}\text { Severe } \\
\text { drought in } \\
\text { Yellow River } \\
\text { Basin }\end{array}$ & & & $\begin{array}{l}\text { (Wang et al., } \\
\text { 2018) }\end{array}$ \\
\hline 1998 & $\begin{array}{l}\text { Floods in } \\
\text { Yangtze River } \\
\text { Basin }\end{array}$ & $\begin{array}{l}\text { Natural Forest } \\
\text { Conservation Program } \\
\text { (on-going) }\end{array}$ & & $\begin{array}{l}\text { (Yin \& Li, } \\
2001)\end{array}$ \\
\hline 1999 & & $\begin{array}{l}\text { Sloping Lands } \\
\text { Conversion Program } \\
\text { (on-going) }\end{array}$ & & $\begin{array}{l}\text { (Bryan et al., } \\
2018 \text { ) }\end{array}$ \\
\hline \multirow[t]{3}{*}{2000} & & $\begin{array}{l}\text { Western Development } \\
\text { Strategy began (on- } \\
\text { going) }\end{array}$ & $\begin{array}{l}\text { Sanjiangyuan Nature Reserve } \\
\text { (provincial reserve) }\end{array}$ & $\begin{array}{l}\text { (Li et al., } \\
\text { 2012) }\end{array}$ \\
\hline & & $\begin{array}{l}\text { Ecological resettlement } \\
\text { (shengtai yimin) policy }\end{array}$ & & $\begin{array}{l}\text { (Ptackova, } \\
2011 ; 2017 \text { ) }\end{array}$ \\
\hline & & & & $\begin{array}{l}\text { (Sternfeld, } \\
\text { 2017) }\end{array}$ \\
\hline \multirow[t]{2}{*}{2001} & & $\begin{array}{l}\text { Wildlife Conservation } \\
\text { and Nature Protection } \\
\text { Program (on-going) }\end{array}$ & & $\begin{array}{l}\text { (Xi et al., } \\
2014) \\
\text { (Deng et al., } \\
2011)\end{array}$ \\
\hline & & $\begin{array}{l}\text { Forest Ecosystem } \\
\text { Compensation Fund } \\
\text { (on-going) }\end{array}$ & & \\
\hline \multirow[t]{3}{*}{2003} & & State Council approved & & (Yeh, 2005) \\
\hline & & $\begin{array}{l}\text { Sanjiangyuan Nature } \\
\text { Reserve to a National } \\
\text { Nature Reserve }\end{array}$ & & $\begin{array}{l}\text { (Sternfeld, } \\
2017) \\
\text { (Ptackova, } \\
2017)\end{array}$ \\
\hline & & $\begin{array}{l}\text { 'Converting } \\
\text { pasturelands into } \\
\text { grasslands' (tuimu } \\
\text { huancao), temporary } \\
\text { grazing ban also being }\end{array}$ & & \\
\hline
\end{tabular}




\begin{tabular}{|c|c|c|c|c|}
\hline & & $\begin{array}{l}\text { advanced in relation to } \\
\text { 'converting } \\
\text { pasturelands into } \\
\text { forests' (tuimu huanlin) }\end{array}$ & & \\
\hline \multirow[t]{2}{*}{2005} & & $\begin{array}{l}\text { State Council approved } \\
\text { implementation of } \\
\text { "Overall Plan for } \\
\text { Ecological Protection } \\
\text { and Construction of } \\
\text { Qinghai Sanjiangyuan } \\
\text { Nature Reserve". }\end{array}$ & & $\begin{array}{l}\text { (Ptackova, } \\
\text { 2011) }\end{array}$ \\
\hline & & $\begin{array}{l}\text { State Council } \\
\text { established } \\
\text { requirements for Phase } \\
\text { I of the Sanjiangyuan } \\
\text { National Ecological } \\
\text { Protection } \\
\text { Comprehensive } \\
\text { Experimental Zone. }\end{array}$ & & \\
\hline 2008 & $\begin{array}{l}\text { Earthquake in } \\
\text { Wenchuan, } \\
\text { Sichuan }\end{array}$ & & & $\begin{array}{l}\text { (Yang et al., } \\
2011)\end{array}$ \\
\hline 2010 & $\begin{array}{l}\text { Earthquake in } \\
\text { Yushu, } \\
\text { Qinghai } \\
\text { Plan for } \\
\text { restoration } \\
\text { and rebuilding } \\
\text { after Yushu } \\
\text { earthquake } \\
\text { approved. }\end{array}$ & & $\begin{array}{l}\text { Qinghai Provincial } \\
\text { Government issued "Several } \\
\text { Opinions on Exploring the } \\
\text { Establishment of } \\
\text { Sanjiangyuan Ecological } \\
\text { Compensation Mechanism" }\end{array}$ & $\begin{array}{l}\text { (Zhang } \\
\text { etal.,2010) } \\
\text { (Sun etal., } \\
\text { 2019) } \\
\\
\text { (Xu \& Lu, } \\
\text { 2013) }\end{array}$ \\
\hline 2011 & & $\begin{array}{l}\text { Grassland Ecological } \\
\text { Protection Program (on- } \\
\text { going) }\end{array}$ & & $\begin{array}{l}\text { (The Central } \\
\text { People's } \\
\text { Government } \\
\text { of the People's } \\
\text { Republic of } \\
\text { China, 2011) }\end{array}$ \\
\hline 2012 & & & $\begin{array}{l}\text { Qinghai "Ranger program" } \\
\text { officially started }\end{array}$ & $\begin{array}{l}\text { (Qi \& Chen, } \\
\text { 2020) }\end{array}$ \\
\hline 2014 & & $\begin{array}{l}\text { Qinghai Sanjiangyuan } \\
\text { National Ecological } \\
\text { Protection }\end{array}$ & $\begin{array}{l}\text { Several Opinions of the } \\
\text { Qinghai Provincial People's } \\
\text { Government on Exploring the }\end{array}$ & $\begin{array}{l}\text { (China News } \\
\text { Network, } \\
\text { 2018) }\end{array}$ \\
\hline
\end{tabular}




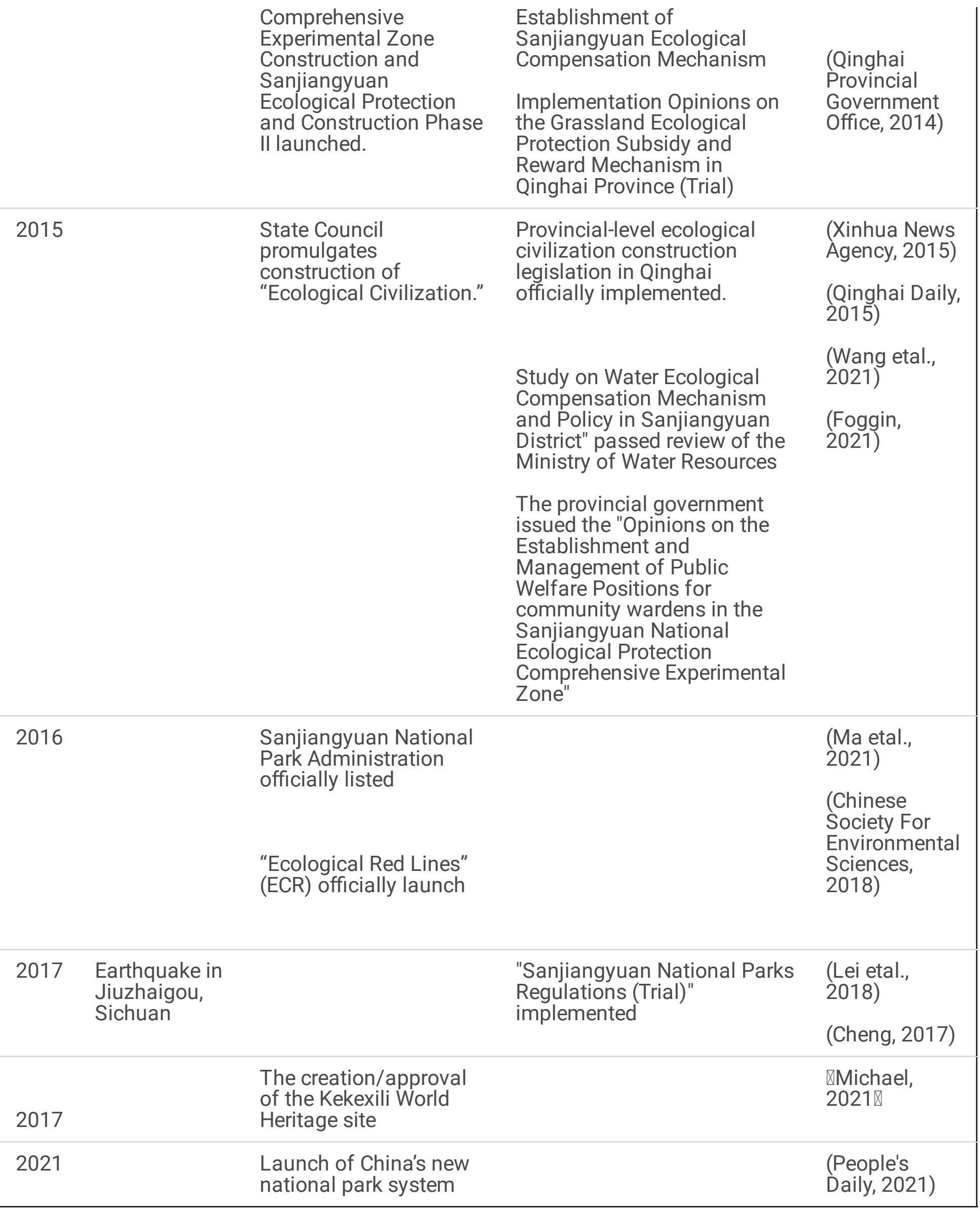


[3] The river known as Lancang in China is known as the Mekong in international parlance. The 4,350 kilometer Mekong River drains southward through China, Myanmar, Laos, Thailand, Cambodia and Vietnam.

[4] Protected areas, or PAs, come in many shapes and forms. PA is a generic term, not to be confused with particular models or approaches such as national parks, nature reserves, and a range of other formal, government-instituted systems. However, in addition, a large portion of the world is conserved through customary practices that de facto have led to conservation of land and resources. At global scale, "IPLCs manage or have tenure rights over at least $\sim 38$ million $\mathrm{km}^{2}$ in 87 countries or politically distinct areas on all inhabited continents. This represents over a quarter of the world's land surface, and intersects about $40 \%$ of all terrestrial protected areas and ecologically intact landscapes" (Garnett et al. 2018). Such community conserved areas often overlap with, but are not the same as, formal PAs (Stevens, Jaeger, and Pathak Broome, 2016). In the history of PAs, including most early national parks largely guided by 'fortress conservation' models, much harm has come to local people, especially IPLCs (Dowie 2009). Overly narrow views about conservation approaches have been partially redressed, however, with recognition of ICCAs or 'territories of life' and other affiliated terms for community-driven conservation. IUCN's Green Standard for Protected and Conserved Areas, for example, now recognizes both PAs and conserved areas, as well as the two complementary but distinct underlying processes necessary for success, namely management of land and resources (i.e., what is done) and perhaps even more importantly the governance of land and resources (i.e., who decides what should be done).

\section{Findings From The Focus Groups}

Our analysis of the focus group results has yielded three main findings. First, the spatial distribution of community wardens inside and outside the national park is unequal and deemed unfair. Second, the establishment of the national park is generally perceived to have improved the environment and people's lives both inside and outside the park, although elderly report that the environment has not yet recovered to the quality it was in the 1960s and '70s and women indicate that more needs to be done to improve women's welfare. Third, some concerns still remain regarding the appropriate management of solid waste and mitigation of human-wildlife conflict in the park. The latter concerns, raised by focus groups, are further supported by discussions with researchers from the Northwest Plateau Institute of Biology, Chinese Academy of Sciences; and they are sometimes amplified in media reports, which tend to sensationalize such problems, overstating their degree and/or their extent).

\section{1 Comparative analysis}

Focus group transcripts were analyzed by the authors and major points of comparison drawn out. Table 2 shows the main results of the comparative analysis. The first comparisons are according to river basin, between the Yellow River Headwaters Park and Lancang River Headwaters Park (2.a); the second by gender (2.b); the third by location, inside versus outside the National Park (2.c); and the fourth by main stakeholder category, government versus resident (2.d). We did not detect major differences between the views according to age (i.e., older versus younger people). 
Table 3. Focus Group result comparisons in the Sanjiangyuan area. 
2.a Comparison between river basins

Similarities

Human-wildlife conflicts are serious, but local residents have little awareness about insurance schemes and the government has not publicized compensation opportunities.
Differences

Lancang River headwaters Park residents feel that residents in the first-level functional area should receive more compensation and enhanced provision of services, compared to residents outside national park boundaries.
Disposal of solid waste is a common problem.
Boundary conflicts are considered to be an important hidden danger of environmental protection in the Lancang River headwaters Park area, both inside and outside of its limits.

Harvesting of Cordyceps is damaging the land both inside and outside the Lancang River headwaters Park.

Yellow River headwaters Park residents believe that people in the middle and lower reaches of the river and future generations benefit most from the park; Lancang River headwaters Park residents believe that local residents within the national park benefit the most.

Tourism should be developed as an income source for local residents.

The establishment of the national park has had positive effects on the environment as well as on the lives of local residents.

The work of the Women's Federation is much better than before.
Yellow River headwaters Park residents believe that local self-employed businesses, hotels, and tourism are most negatively affected by the park; residents in Lancang River headwaters Park believe that people outside of the park are most negatively affected.

Residents in the Lancang River basin advocate restoring the pasture lands (grasslands) and controlling plateau pika ${ }^{[5]}$.

Young people need more job opportunities and everyone needs more training in financial management.

There is no gender preference in selection of community wardens in the "One household, one post" system.

Residents living outside the park should also be assigned as community wardens with one position per household.

Environmental quality is reported as having significantly improved over 10 years $^{[6]}$. 
each community ranger is insufficient.

Table 2.b Comparisons between women and men

Similarities

More information is needed about women's health.

More comprehensive medical facilities are needed, especially related to women's health and mother and child health.

\section{Differences}

Men feel that female community wardens are more attentive, confident and diligent. In the past, women were not allowed to speak loudly in public, but they are now able to.
Young people need more job opportunities.
Women cannot get business loans, but men can, and women want to be treated fairly in this regard.

There is a lack of knowledge about financial management. (This issue also raised by both government officials and residents.)

Table 2.c Comparisons between inside/outside the National Park Similarities

Tourism activities have been negatively affected by National Park rules and should be further developed (This issue was raised by both government officials and residents.)
Differences

Residents outside the national park feel unfairly treated as they are not allocated a community warden. Most environmental projects are first implemented inside the national park.
Young people need more job opportunities. (This issue was also raised by both government and resident focus groups.)
Tourism is prohibited in the national park due to focus on strict ecological protection, whereas there are few restrictions outside the national park.

Each family outside the park should also benefit from the one household, one post policy, with a salary of 1400-1800 yuan / month. 
Table 2.d Comparisons between Government's and residents' awareness

Similarities

Both groups recognize the tourism industry has been affected, and both consider that appropriate tourism should be developed.

\section{Differences}

Residents are unaware of the possibility of compensation for damages (losses) arising from human-wildlife conflict.

Source: authors

\subsection{Implementation of the community warden program}

Almost all residents believe that the establishment of national parks has had a large positive impact on the environment and residents' lives. The establishment of the "one household, one post" ecological management system has transformed (or in some ways, re-established) residents from simple users to guardians of the grassland. It appears that local residents feel well qualified for this job, and also feel a sense of accomplishment. Significantly, living standards have reportedly improved, as also has environmental quality within the national park.

The main selection criteria to participate as a community warden is to be between 18 and 55 years of age and capable of physical labour. Each family nominates the family member who will occupy the community warden position, with no gender discrimination noted. However, residents outside the national park do not benefit from this system to the same extent. First, the "one household, one post" has not been extended to all households outside but only those living in close vicinity of the park. Second, there are fewer environmental projects such as wildlife monitoring, grassland restoration and plateau pika control

outside of the national park ${ }^{[7]}$. Although the local government has taken some measures to reduce the gap between people living inside and outside of the park boundary, such as skills training, more could be done for people living on the outside. Yet, due to stricter ecological protection and also the presence of wildlife in the national park, residents in that area do incur some additional costs (e.g., inability to benefit from tourism, weaker infrastructure, more human-wildlife conflict), which is deemed by authorities to justify the differential. Broadly speaking, though, local residents recommend that those living outside of the park should also benefit from the "one household, one post" policy, but with possibility for this to be at a reduced monthly salary of 1,400-1,800 CNY (219.27-281.92 USD) per month.

\subsection{Environment}

Elderly residents born in more challenging times said their lives have seen tremendous changes and they perceive national park policies as a form of social assistance - relative to their prior socio-economic deprivations, which current policies are now addressing at least in part. On the other hand, they report that current environmental quality is not as good as what they experienced when were young. Few if any 
plastic bags or plastic bottles were present in the 1960 s to ' 80 s, and there were no notable problems with small burrowing mammals. Between 20 and 30,000 mu (1,333-2,000 ha) of grassland provided enough pasture for 1,500-1,600 Tibetan sheep, but now the same area can only support 500-600 sheep. In the past, Tibetan herders used oil lamps for lighting and there were no batteries or coal for heating, thus there was little pollution of the environment. Many respondents thus felt that environmental quality in more recent times, from 2000 to 2016, was not very good. However, from 2016 to the present (i.e., since the establishment of the national park pilot), environmental quality is reported to have greatly improved, though it is still not as good as in the more distant past. Young residents also reported that environmental quality improved significantly over the ten years period ${ }^{[8]}$.

With all such statements, however, while there may be correlation, we must not immediately imply causality when/where none can be directly/properly attributed. For example, a major snowstorm in 1985 that caused great losses to livestock and wildlife and a period of aridification with rapid extension of sand dunes and losses of streams and lakes in the 1980s and '90s and even into the early 2000s could also be behind other observations; and more recent noted changes may simply be 'recovery' from these

abnormal situations (which are not themselves representative of longer-term baselines or averages) ${ }^{[0]}$.

Affected by increasing human economic activities as well as global climate change, the conflicts between people and nature in the Sanjiangyuan area have gradually increased. The most serious grassland degradation in the Sanjiangyuan area basically took shape around the mid 1970s, and generally continued until the mid 1990s. No sharp increase in grassland degradation occurred since then until the present (Liu et al., 2008).

\subsection{Women}

The selection of community wardens has not been discriminatory according to gender, and thus has upheld the principle of gender equality. Male residents generally acknowledge that female community wardens are more attentive and diligent than their male counterparts and that they have made vital contributions to environmental protection. The establishment of national parks has undoubtedly strengthened women's confidence. Most recently, the Women's Federation organized female wardens and female members during the Covid-19 pandemic to make donations and hold lectures on the prevention of transmission of the virus and organized them to visit impoverished student families and conduct community clean-up campaigns. At present 6-7 lectures are held each year, and the women's groups hope to increase the number of lectures on women's health. It was also noted that women desired better health facilities, e.g. for gynaecological health care. In addition, women cannot easily obtain commercial loans, while men can; women participants in the FGs expressed their wish to be treated fairly in this regard.

\subsection{Ecotourism}

Almost all residents think it is important to develop ecotourism activities. For example, residents of Huanghe and Huashixia towns in the headwaters of the Yellow River are collectively calling for the development of 'tourist villages' to contribute to improving their livelihoods. Yet tourism has been banned 
since May 2017 in national parks. The establishment of national parks has thus had a serious impact on the local industry, such as locally owned, operated and staffed hotels and restaurants. Residents believe, however, that a viable model could be developed to meets both environmental and development goals, by limiting the number of tourists and offering more exclusive high-end ecotourism experiences.

\subsection{Local ecological knowledge}

Residents near the Yellow River headwaters National Park discussed approaches for better restoring pastures. They proposed that Tibetan sheep should be used instead of yaks on degraded pastures, as Tibetan sheep fertilize the soil through their manure and the particular trampling action of their hooves (a behaviour that yak do not exhibit; Long et al., 2008) ${ }^{[10]}$.

In the Lancang River headwaters National Park, local residents expressed concern regarding the use of poisons to eliminate the plateau pika; which have successfully eliminated some populations of the targeted species, but in addition also have led to loss of many other wildlief species including their natural predators - and thus, the use of poisons has caused serious long-term damage to the pasture. Residents instead argued in favour of natural methods, such as erecting scaffolds to attract more raptors (birds of prey) to grassland areas, allowing them to increase in number and control the pika through their hunting behavior.

Additionally, local residents proposed that ice-breaking operations be implemented in relevant parts of the national park. They reported that grassland fires occur every year because of the freezing of lakes in winter, leading to formation of natural convex mirrors that concentrate sunlight, causing grassland fires. The herders themselves already carry out ice-breaking operations each year to avoid such fires, but they highlight that further support in this would be helpful to them.

\subsection{Other insights from the focus groups}

Residents in the headwaters of the Yellow River believe that the construction of the national parks will generate most benefits for residents in the middle and lower reaches of the rivers, as well as for future generations. Although upstream residents are making sacrifices, they are for the most part willing to take such responsibility for protecting the headwaters. Residents in the Lancang River headwaters, for their part, believe that it is they, the local residents, who will benefit most from the construction of the national park.

In the latter context, Zaduo County is the best place for collecting Cordyceps sinensis. ${ }^{[1]}$ Residents in the main Cordyceps collection area in the Lancang headwaters wish to manage the area by themselves. Since a large number of outsiders dig Cordyceps every year, the damage to the environment is signficant. Zaduo government allowed outsiders to enter the county to dig Cordyceps prior to 2007, but this practice was then banned for nearly a decade. Since 2018, however, outsiders have been allowed again to harvest Cordyceps after June $30^{\text {th }}$ each year, even though studies have shown that it still reproduces in July. Local residents feel that outsiders who harvest Cordyceps do not take sufficient care to backfill the holes 
that they dig during harvesting, and also they are more likely to leave litter behind. Local residents would therefore prefer the ban on outsiders' harvesting of Cordyceps to be more flexible and not limited to specific dates, allowing for more adaptive or responsive management.

Local government officials also reported that border conflicts consitute a hidden (unrecognized) serious threat for environmental protection in the Sanjiangyuan National Park. The southern headwaters of the Yangtze River is located near the border of Qinghai Province and Tibet Autonomous Region. The national park model encourages conservation through community wardens, however the nearby area in Tibet Autonomous Region is designated as a "mixed pastoral zone" where Tibet and Qinghai herdsmen rely on a combination of livestock grazing and the harvesting of Cordyceps, creating possibility for conflicts at their interface.

Zhaqing Town has a solid waste disposal facility, but other towns in the area do not. Residents report that there are insufficient waste management facilities and it is very difficult to transport solid waste from the pastoral areas to the county headquarters due to the poor quality roads, high cost of fuel, and the community wardens' low monthly salary of 1,800 CNY.

Residents both inside and outside the Lancang River headwaters National Park believe that residents in the primary protection area should receive more compensation and better government services. For example, Chadan Town is located in the core area and construction of a planned national highway was cancelled due to the establishment of the national park. Roads remain poor, making it difficult to access services and markets, transport garbage, or for students to go to school.

Local residents generally believe that the quality of education should be improved, too, and they wish to be trained in financial management knowledge and skills. Residents also highlight the importance of provided more job opportunities for young people throughout the region.

Overall, human-wildlife conflict is presently one of the most difficult problems, seriously threatening the livelihoods (and sometimes lives) of local residents. However, few residents are aware of the possibility to buy insurance, and the government has not publicized the possibility. Now the life cycles of snow leopards (Panthera uncia), bears (Ursus arctos pruinosus) and Tibetan wolves (Canis Lupus chanco) are changing. Bears no longer hibernate and they no longer appear to be afraid of humans. These wild animals have caused extensive damage to residents' houses, and also seriously threaten the residents' personal safety - most people are now fearful living in pastoral areas. Significantly, government-backed compensation plans for losses incurred in this way are not yet adequately planned or implemented.

Finally, many respondents note that the two protection systems of nature reserves and national parks coexist, with many management contradictions. One example is that the important headwaters of the Dangqu and Lancang Rivers south of the Yangtze River are not included in the national parks. Another example is Sulu, Jieduo and Sahuteng towns in Zaduo County, which also constitute important headwaters for the Lancang and Yangtze Rivers but not included in the national parks. From the 
perspective of the integrity of ecosystem as well as integrity in administration, it is widely considered that these areas should be included in the parks.

[5] Further, competition [of plateau pika] with livestock for food has been widely reported, especially in areas where pika densities were highest (Sun \& Zhao, 2009); more recently, though, this has largely been refuted as more detailed vegetation and behavioral studies have recognized the plateau pika's fundamental role as keystone species. Extensive targeted poisoning campaigns aiming to control populations occurred repeatedly since the 1950s (Jiang \& Xia, 1987), but over the past decade these have largely ceased.

[6] The National Development and Reform Commission's comprehensive evaluation report on the ecological effects shows that the main protection objects in the Three Rivers Source Area have been better protected and restored, the quality of the ecological environment has been improved, the ecological functions have been consolidated, the water conservation has increased year by year, the grassland coverage, and grass production The volume has increased by $11 \%$ and $30 \%$ respectively over 10 years ago.

[7] Although we mention these so-called ecological activities, we are not in fact 'endorsing' them, as some work counter to biodiversity conservation principles, especially the poisoning campaigns, which are effectively annihilating a very important keystone species of the plateau (Smith \& Foggin 1999). [8] Our results are "what the respondents have reported" and "what they feel/consider" - but not necessarily the actual case, i.e. may not be confirmed through other means. Timelines also can be blurred; and the fact the national park pilot began in 2015 does not mean that changes noted since then are necessarily due to the park's creation (even if reported by some respondents as such). Memory bias and the possibility that responses being could be influenced by the context of the FGs, including audience (i.e. who is present, e.g. government officials) are here noted, too.

[9] It's worth noting that peoples' perceptions and reporting thereof, not actually a documenting of the substance of what is being reported.

[10] While yak and sheep do indeed have different behaviours... there is also value in having diverse grazers, rather than single kind of grazing animal as multiple/varied pressures can lead to more resilient grasslands.

[11] In the Tibetan region, Cordyceps sinensis is widely known as yartsa gunbu (Tibetan), chongcao (Chinese), or "summer grass, winter worm." Chongcao has been used in traditional medicine across China and the Himalayan region for centuries to treat ailments ranging from cancer and kidney disease to inflammation and aging. In more recent years it has earned the nicknames of "Himalayan Viagra" and "Himalayan gold." Chongcao is mainly found in the alpine zone above 4,000 meters above sea level. The production of chongcao in Yushu Tibetan Autonomous Prefecture of Qinghai Province accounts for $60 \%$ of the country's total production. This is in the heart of the Sanjiangyuan region. Due to the large size, good quality and high proportion of chongcao produced in this area, the local harvest can directly affect the price of chongcao nationally. Therefore, Zaduo county is also known as "the first county of China for chongcao" (Sulek, 2019). 


\section{Discussion}

In this section we draw upon the results of the policy review and focus group discussions to reflect on a number of important topics and questions of high relevance to the goals of environmental protection.

\subsection{Is the community warden program a pro-woman intervention?}

In the Sanjiangyuan National Park, the "one household, one post" model is consistent with the principle of gender equality. Each household nominates one warden and all wardens regardless of gender are paid the same monthly salary of CNY 1800 . Male focus group participants asserted that female community wardens are more attentive and diligent than male wardens and that women also have become more assertive and confident and some have also begun to serve as village leaders. Despite these proposed gains, however, even with the establishment of the Sanjiangyuan National Park there remain some limitations for women. For example, women in the region still cannot obtain commercial loans, while men can, and women lack access to reproductive health services. As women's empowerment would be beneficial for both development and environmental protection (Duflo,2012), we recommend that the gender effects of the National Park be fully assessed and remedial actions taken.

\subsection{Community wardens}

The Sanjiangyuan National Park has a strong "workforce" (shengtai guanhuyuan) of community wardens. The wardens not only serve as environmental monitors, but also as protectors who detect infractions and serve as liaisons between the National Park and the wider community in which they live. The term 'shengtai guanhuyuan' that permeates much of China's view on national parks is still somewhat oppositional, i.e. that the national parks need to be guarded from people who otherwise would contravene the regulations. Yet there is positive movement too, such as through the continuing development of 'comanagement' approaches, which are somewhat more participatory and inclusive - even if not to the extent observed in some other circumstances worldwide (Brooks et al., 2013).

To promote the organic unity of ecological protection and improvement of people's livelihoods, starting with the first phase of the Sanjiangyuan ecological protection and construction project, Qinghai Province has been exploring the implementation of "one household, one post". As of May 2021, Qinghai Province has established a total of 81,668 community wardens, and arranged 1.35 billion CNY in subsidies every year (including 1.16 billion CNY from the provincial government in Qinghai Province and 190 million CNY from the central government). Especially since the pilot implementation of the Sanjiangyuan National Park system began, Qinghai Province has innovatively implemented the "one household one post" system for ecological management and protection in the pilot area of the Sanjiangyuan National Park system based on actual local conditions, covering all herdsmen in the park area. Including 53 villages in the park, each household has a community warden, for a total of 17,211 community wardens assigned to their new roles, with average annual household income increased by 21,600 CNY (Sanjiangyuan National Park, 2021). 
The Park now has 19 management and protection brigades and 64 management and protection squads (Peng 2018; Sanjiangyuan National Park, 2021). Poverty alleviation activities have been planned, although more could be done to advance the dual objectives. Appropriate training and tools would strengthen the ability of community wardens to help their communities develop in socio-economic terms and to achieve the protection goals of the national park (Foggin, 2018).

The towns in Zaduo County are similar in geographical environment and have similar importance to the protection of the park. However, three towns - Sulu, Jieduo and Sahuteng - have not been incorporated into the national park, resulting in different incentives than people living in towns located within the park boundaries. For example, community wardens living in these three towns need to carry out patrol work on grasslands far away from their homes. It is estimated that such community wardens need to incur an additional cost of 600-1,000 CNY / month for transportation (Sanjiangyuan National Park,2021).

Another challenge with the community warden program is their formal education levels, which make it challenging to meet the work required to build an international and modern national park. Guards lack patrol equipment, technical measures for ecological protection are incomplete, and scientific and technological support is not strong. It is therefore recommended that the relevant authorities make further investments in the systematic training and equipment of community wardens (Shang, 2019).

\subsection{Promoting conservation and community development through ecotourism}

Ecotourism provides both opportunities and challenges. Since becoming a national park pilot, the Yellow River headwaters National Park Administration has issued the "Notice on Prohibition of Tourism Activities in the Zhaling-Eling Lake and Xingxinghai Nature Reserve Zones", combined with special enforcement actions known as "Green Shield" and "Spring Thunder". These enforcement operations dispatched 700 personnel in 136 intensive patrols to patrol $80,000 \mathrm{~km} 2$ of park land. Over 6,000 tourists were persuaded to return to more than 2,300 vehicles, thus protecting the grasslands, wetlands, and wild animals inside and outside the park (Sanjiangyuan National Park, 2021).

Although tourism has been prohibited in national parks since the establishment of the pilot project, some high-end eco-tourism activities have been gradually carried out since June 2020 (Sanjiangyuan National Park, 2021). In ecologically important but fragile areas, namely the upper reaches of the Yangtze, Yellow and Mekong Rivers, the government is trying to find ways to diversify and develop local economies to reduce residents' dependence on livestock grazing and Cordyceps collection. Both the public and private sectors recognize that the rich cultural and natural assets, namely the extraordinary mountain and grassland landscape, the unique local pastoral culture and the rich biodiversity of the region provide great potential for the development of tourism in the region. With appropriate policies, large economic benefits can be brought to the community; however, without appropriate policies, there could be serious leakage in the tourism industry, with most of the social and economic benefits flowing to external entrepreneurs and enterprises (Foggin and Yuan, 2020). As many communities around the world have experienced, the potential of ecotourism is unique in its ability to harmonize environmental protection and community development (Li, W., \& Han, N., 2001), yet a cautious approach should be taken by ecotourism 
practitioners, government agencies and community groups to strengthen the eco-tourism strategy of all protected areas and other nature reserves in the country (Linetti, 2019, Foggin and Yuan, 2020).

According to our experience and observations over the past 4 years, and elsewhere in the literature (Foggin, 2018), we conclude:

(1) Like other sectors, communities that participate in eco-tourism decision-making tend to show greater sense of corporate ownership, so they tend to participate more, resulting in deeper development impact and greater project success (also see Ma et al., 2021).

(2) Strengthening civil society is important for long-term success, including capacity building, leadership development and promoting the establishment of professional and activity-based networks for encouragement, acceptance and peer-to-peer learning. It has been found in many instances that this approach can increase the sense of hope among local residents, leading to more people participating in the development of new options. Hope is a powerful force that can combine human, natural, economic and political realities to lead sustainable development solutions (Lybbert and Wydick, 2018; Foggin and Yuan, 2020).

\subsection{Coordination of environmental protection and development}

The complex and context-specific relationship between the livelihoods of residents in the national park and natural protection pose many challenges for national park management. Although a long-term interdisciplinary approach may be required to fully understand the relationship between people and the environment in a particular national park, the reality is that most management decisions are made by protected area staff without undertaking such in-depth studies (Wang et al., 2012). One potential entry point for management to understand the relationship between people and parks and to improve their management is to work from the perspective of local people's perceptions and understanding of the particular park (Ma, Xu, Xing, Shu, \& Sang,2020).

The Sanjiangyuan National Park includes some towns and villages in addition to vast rural areas. However it is difficult to obtain national administrative permission for planning water, electricity, roads and other civil engineering projects.

Furthermore, the Sanjiangyuan region has had indigenous inhabitants since ancient times, and these Indigenous peoples and local communities (IPLCs) are themselves an important part of the integrated socioecological ecosystem; protection of nature without people is unrealistic. Only when local people's well-being is also considered can environmental protection be most effective. Human development and ecological protection are the core issues in the construction of the Sanjiangyuan National Park, even though most difficult to solve. Indeed, conflict, compatibility, or complementarity between the demands created by livelihood activities and conservation objectives have been the focal point of much discussion over the last two decades. There has been considerable debate as to the effectiveness of Integrated Conservation and Development Projects that, as the name implies, seek to link conservation and 
livelihood objectives (Ma, Xu, Xing, Shu, \& Sang, 2020). Promisingly, though, human development needs and environmental carrying capacity could be assessed through a co-management approach that respects local herders' abilities to establish appropriate limits for local ecological contexts and protection requirements of different parts of the National Park area (Wang et al., 2021).

\subsection{Human-wildlife conflict(HWC)}

The number of snow leopards (Panthera uncia) in China dropped sharply in the 1980s due to poaching. In recent years, with the increased attention given to ecological and social protection, the number of snow leopards has stabilized and the estimated number of snow leopards across the entire Sanjiangyuan area now exceeds 1,000 individuals. The area is now recognized in academic literature as excellent habitat with one of the densest populations of snow leopards in the world (Yan, 2017) and the population of wild animals of all sorts in the Sanjiangyuan area has increased significantly (Liu et al., 2016). The adverse consequence of this, though, is that conflicts between humans and animals have intensified. Wild animal injuries occur frequently and the safety of the lives, livestock and property of local herdsmen are threatened. One remedial action is the provision of wildlife damage compensation funds with provincial, prefectural, and county-level finances respectively responsible for reimbursing $50 \%, 25 \%$, and $25 \%$ of herders' losses. In reality, though, the compensation standard for injuries and losses is still too low, and the total funds available for compensation are low. Only provincial and county financial compensation has been implemented, while state-level and prefectural compensation has not been implemented. It is recommended to speed up the establishment of a sound compensation mechanism for wild animals, so that the herders can receive due compensation for participating in ecological protection and enjoy more benefits brought by the construction of ecological civilization (Tamrat et al., 2020; Palminteri, 2016).

\section{Conclusions}

Critical policy analysis was used to assess the Sanjiangyuan National Park in China's Qinghai Province, a massive area of national and global importance for watershed, biodiversity and cultural conservation. A critical review of policy documents and the scholarly literature clarifies the recent history and practice of integrated environmental management and community development in the area, culminating now in the "one household, one post" co-management system. Thousands of local women and men are involved as community wardens, helping to monitor and protect the health of the alpine ecosystem. Implementation of this system has massive implications for the ecosystems and for the well-being of the many local communities that are located within and adjacent to the National Park.

Focus groups meetings with 12 groups of residents and local government officials - who vary by gender, occupation, river basin and location inside or outside of the park boundaries - unearthed many positive and negative issues that are felt by local residents and local officials. One of the most salient of these issues is perceived unfairness to people who live outside but adjacent to the park, who bear many of the costs but few of the benefits associated with the national park. Another salient issue is the limited capacity of the community wardens to effectively perform their monitoring, conservation, and community 
liaison roles. Eco-tourism, public services such as waste management and health care, and compensation for wildlife damage are also noted as important issues. Addressing these, and tapping into the indigenous ecological knowledge of herders, will be important for the continued success and evolution of this co-management model.

\section{Declarations}

Author Contributions: Conceptualization, T.M. and B.S.; Data curation, T.M.; Formal analysis, T.M., J.M.F. and B.S.; Funding acquisition, W.G.S.; Investigation, T.M.; Methodology, T.M. and B.S.; Project administration, T.M.; Supervision, W.G.S., B.S. and L.S.Z.; Validation, B.S and J.M.F..; Writing-original draft, T.M.; Writing-review \& editing, T.M., B.S. and J.M.F.

Funding: This work was supported by Second Tibetan Plateau Scientific Expedition and Research of MOST of China (2019QZKK0401); Sanjiangyuan National Prark Joint Research Project of CAS and Qinghai Province (No. LHZX-2020-05).

Acknowledgments: We wish to thank the Sanjiangyuan national park administration for their devoted contribution to the study. In addition, we express our appreciation to the government staff of Sanjiangyuan national park management committee for sharing informational material to participants of the study. We also acknowledge the many local people who took time to share their knowledge and perspectives during the Focus Groups.

Conflicts of Interest: The authors declare no conflict of interest.

\section{References}

1. United Nations General Assembly. Resolution 70/1: Transforming Our World: The 2030 Agenda for Sustainable Development. 2015. Available online: http://undocs.org/A/RES/70/1 (accessed on 27 October 2016).

2. Bryan, B. et al. China's response to a national land-system sustainability emergency. Nature, 559(7713), 193-204 (2018). doi: 10.1038/s41586-018-0280-2.

3. Foggin, J. M. Environmental conservation in the Tibetan Plateau region: lessons for China's Belt and Road Initiative in the mountains of Central Asia. Land, 7(2), 52 (2018).

4. Breitkreuz, R., Stanton, C. J., Brady, N., Pattison-Williams, J., King, E. D., Mishra, C., \& Swallow, B. The Mahatma Gandhi national rural employment guarantee scheme: A policy solution to rural poverty in India? Development Policy Review, 35(3), 397-417 (2017).

5. Breitkreuz, R., \& Swallow, B. Critical Policy Analysis: Using Focus Groups to Explore Social Policy in India (2019). SAGE Publications Ltd.

6. Novotn, J., Kubelková, J., \& Joseph, V. A multi-dimensional analysis of the impacts of the Mahatma Gandhi National Rural Employment Guarantee Scheme: A tale from Tamil Nadu. Singapore Journal of Tropical Geography, 34(3), 321-341 (2013). 
7. Morgan, D. L. Focus Groups As Qualitative Research. Modern Language Journal, 82 (1997).

8. Foggin, J.M. Conservation Issues: Mountain Ecosystems. Reference Module in Earth Systems and Environmental Sciences. Elsevier: Toronto, Canada, 2016. Available online: https://doi.org/10.1016/B978-0-12-409548-9.09199-5 (accessed 15 March 2018).

9. Kreutzmann, H. Pamir or Pamirs: Perceptions and Interpretations: Springer International Publishing (2016).

10. Squires, V. R., \& Lu, Q. Sustainable Land Management in Greater Central Asia: An Integrated and Regional Perspective (2017).

11. Yao, T.D. et al. Third Pole Environment (TPE). Environmental Development (2012).

12. Long, R. et al. The Yak Grazing System on the Qinghai-Tibetan Plateau and Its Status. Rangel. J. 30, 241-246 (2008).

13. Gruschke, A. Tibetan pastoralists in transition. Political change and state interventions in nomad societies. Pastoral practices in High Asia, 273-289 (2012). Springer, Dordrecht.

14. Cong, W. et al. Temperature sensitivity of spring vegetation phenology correlates to within-spring warming speed over the Northern Hemisphere. Ecological Indicators, 50(mar.), 62-68 (2015).

15. Yan, J. et al. Determinants of Engagement in Off-Farm Employment in the Sanjiangyuan Region of the Tibetan Plateau. Mountain Research and Development, 37(4), 464-473(2017).

16. Foggin, J. M. Depopulating the Tibetan grasslands. Mountain Research and Development, 28(1), 2631 (2008).

17. Shao, Q. Q. et al. Integrated assessment on the effectiveness of ecological conservation in Sanjiangyuan National Nature Reserve. Geographical Research, 32(9), 1645-1656(2013).

18. Du, F. Ecological resettlement of Tibetan herders in the Sanjiangyuan: a case study in Madoi County of Qinghai. Nomadic Peoples, 116-133(2012).

19. Sheehy, D. P., Miller, D., \& Johnson, D. A. Transformation of traditional pastoral livestock systems on the Tibetan steppe. Science et changements planétaires/Sécheresse, 17(1), 142-151(2006).

20. Li, J. et al. Defining priorities for global snow leopard conservation landscapes. Biological Conservation, 241, 108387(2020).

21. Wu, J. et al. Value capture mechanisms, transaction costs, and heritage conservation: A case study of Sanjiangyuan National Park, China. Land Use Policy, 90, 104246(2020).

22. Xinhua. China to Set Up National Park System. Available online: http://english.gov.cn/policies/policy_watch/2017/09/27/content_281475888517430.htm (accessed on 15 March 2018).

23. Shang, K.Y. "China Sees Enhanced Efforts in Protection of National Parks." People's Daily, March 18, 2019.

24. Manandhar, S. et al. Climate Vulnerability \& Adaptive Capacity of Mountain Societies in Central Asia: MSRI Research Report Series (2017). 
25. Cao, M., Peng, L., \& Liu, S. Analysis of the network of protected areas in China based on a geographic perspective: current status, issues and integration. Sustainability, 7(11), 15617-15631 (2015).

26. Guo, Z., \& Cui, G. Establishment of nature reserves in administrative regions of mainland China. PLoS One, 10(3), e119650 (2015).

27. China Global Television Network (CGTN). How China's Ecological 'Red Line' Fits into a Much Larger Plan. CGTN America. Available online: https://america.cgtn.com/2017/03/10/how-chinasecological-redline-fits-into-a-much-larger-plan (accessed on 12 April 2018).

28. Zhu, P. et al. The Impacts of Human Activities on Ecosystems within China's Nature Reserves. Sustainability, 11(23), 6629 (2019).

29. Cao, S. et al. Balancing ecological conservation with socioeconomic development. Ambio, 1-6 (2021).

30. Xu, W. et al. Strengthening protected areas for biodiversity and ecosystem services in China. Proceedings of the National Academy of Sciences, 114(7), 1601-1606(2017).

31. Li, J. et al. Streamlining China's protected areas. Science, 351(6278), 1160(2016).

32. He, M., \& Cliquet, A. Challenges for Protected Areas Management in China. Sustainability, 12(15), 5879(2020).

33. Sheng, G. et al. Moving toward a Greener China: Is China's National Park Pilot Program a Solution?. Land, 9(12), 489 (2020).

34. Zhao, J. et al. Landsenses ecology and ecological planning toward sustainable development: Taylor \& Francis(2016).

35. China Daily. "First National Park Will Be Officially Established This Year,"January 9, 2020.

36. Sanjiangyuan National Park, "Sanjiangyuan National Park: An ecological model for the construction of a beautiful China." January 12, 2021. Sanjiangyuan National Park. http://sjy.qinghai.gov.cn.

37. Hu, Y., Huang, J., \& Hou, L. Impacts of the grassland ecological compensation policy on household livestock production in China: an empirical study in Inner Mongolia. Ecological Economics, 161, 248256 (2019).

38. Hansen, M. H., Li, H., \& Svarverud, R. Ecological civilization: Interpreting the Chinese past, projecting the global future. Global Environmental Change, 53, 195-203(2018).

39. Maxwell, S.L. et al. Area-based conservation in the twenty-first century. Nature 586, 217-227 (2020). https://doi.org/10.1038/s41586-020-2773-z

40. Garnett, S. T. et al. A spatial overview of the global importance of Indigenous lands for conservation. Nature Sustainability, 1(7), 369-374 (2018).

41. Stevens, S. et al. Recognising and respecting ICCAs overlapped by protected areas. Report for the ICCA consortium(2016).

42. Sobrevila, C. "The Role of Indigenous Peoples in Biodiversity Conservation: The Natural but Often Forgotten Partners"(2008). Washington, DC. 
http://documents.worldbank.org/curated/en/995271468177530126/The-role-of-indigenous-peoplesin-biodiversity-conservation-the-natural-but-often-forgotten-partners.

43. Wang, Y. "China's First National Park, an Experiment in Living with Snow Leopards" (2019).

Mongabay. 2019. https://news.mongabay.com/2017/05/chinas-first-national-park-an-experiment- inliving-with-snow-leopards/.

44. Foggin, J.M. Promoting Biodiversity Conservation and Community Development in the Sanjiangyuan Region. Proceedings of a conservation planning meeting, with agreed priority action points. Conservation planning meeting co-hosted by Plateau Perspectives, Upper Yangtze Organization, Zhiduo County Government, Sanjiangyuan National Nature Reserve (2005). Yushu, Qinghai, China, Sep 30 - Oct 13, 2005. Plateau Perspectives: Xining, China.

45. Li, W.J. et al. Three Gorges Project: benefits and challenges for shipping development in the upper Yangtze River(2020), International Journal of Water Resources Development, DOI:

10.1080/07900627.2019.1698411

46. Wang, F. et al. Study of the temporal and spatial patterns of drought in the Yellow River basin based on SPEl. Sci. China Earth Sci. 61, 1098-1111 (2018). https://doi.org/10.1007/s11430-017-9198-2

47. Yin, H., \& Li, C. Human impact on floods and flood disasters on the Yangtze River. Geomorphology, 41(2-3), 105-109 (2001).

48. Li, W., Liu, Y. J., \& Yang, Z. Preliminary strategic environmental assessment of the Great Western Development Strategy: safeguarding ecological security for a new western China. Environmental management, 49(2), 483-501(2012).

49. Ptackova, J. Sedentarisation of Tibetan nomads in China: Implementation of the Nomadic settlement project in the Tibetan Amdo area; Qinghai and Sichuan Provinces. Pastoralism: Research, Policy and Practice, 1(1), 1-11(2011).

50. Ptackova, J. Orchestrated Environmental Migration in Western China. In Routledge Handbook of Environmental Policy in China, 223-236(2017). Routledge.

51. Sternfeld, E. Routledge Handbook of Environmental Policy in China(2017). Taylor \& Francis.

52. Xi, W. et al. Challenges to sustainable development in China: a review of six large-scale forest restoration and land conservation programs. Journal of sustainable forestry, 33(5), 435-453 (2014).

53. Deng, $\mathrm{H}$. et al. Forest ecosystem services and eco-compensation mechanisms in China. Environmental management, 48(6), 1079-1085 (2011).

54. Yeh, E. T. Green governmentality and pastoralism in western China:'converting pastures to grasslands'. Nomadic peoples, 9(1-2), 9-30 (2005).

55. Yang, W., Wang, D., \& Chen, G. Reconstruction strategies after the Wenchuan earthquake in Sichuan, China. Tourism Management, 32(4), 949-956 (2011).

56. Zhang, Y., Xu, L., \& Chen, Y. T. Source process of the 2010 Yushu, Qinghai, earthquake. Science China Earth Sciences, 53(9), 1249-1251(2010). 
57. Sun, L. et al. Religious belief and Tibetans' response to earthquake disaster: a case study of the 2010 Ms 7.1 Yushu earthquake, Qinghai Province, China. Natural Hazards, 99(1), 141-159 (2019).

58. Xu, J., \& Lu, Y. A comparative study on the national counterpart aid model for post-disaster recovery and reconstruction: 2008 Wenchuan earthquake as a case (2013). Disaster prevention and management.

59. The Central People's Government of the People's Republic of China. Available online: http://www.gov.cn/gzdt/2011-09/29/content_1959759.htm (accessed on 13 October 2021).

60. Qi J.Y., Chen X.L. Resettlement and adaptation of ecological migrants in the Three Rivers Headwaters Region. [J]. Ethnic studies, 2020, (4): 74-86. (in Chinese)

61. China News Network. Available online: http://124.205.185.62:8080/main/146/20180207/1074369.html_(accessed on 13 October 2021).

62. Qinghai Provincial Government Office. Available online: http://www.qh.gov.cn/ztzl/system/2014/10/24/010138566.shtml_(accessed on 13 October 2021).

63. Qinghai Provincial Government Office. Available online: http://www.qh.gov.cn/ztzl/system/2014/10/24/010138571.shtml_(accessed on 13 October 2021).

64. Xinhua News Agency. Available online: http://www.gov.cn/guowuyuan/201509/21/content_2936327.htm (accessed on 13 October 2021).

65. Qinghai Daily. Available online: http://www.qh.gov.cn/dmqh/system/2017/07/12/010272766.shtml (accessed on 13 October 2021).

66. Wang, Y. et al. Ecological Conservation Redline will promote harmony between humans and nature in the future. Ambio, 50(3), 726-727 (2021).

67. Foggin, J.M. We still need the wisdom of Ubuntu for successful nature conservation. Ambio $50,723-$ 725 (2021). https://doi-org.ezproxy.library.ubc.ca/10.1007/s13280-020-01402-z

68. Ma, T. et al. Resident Willingness to Pay for Protected Area Ecotourism Resources and Associated Factors in Sanjiangyuan National Park, China. Journal of Resources and Ecology, 12 (2021).

69. Chinese Society For Environmental Sciences. Available online: http://www.chinacses.org/hjkp_23038/hbkpxw/201811/t20181127_675124.shtml (accessed on 13 October 2021).

70. Wang, Y. et al. Ecological Conservation Redline will promote harmony between humans and nature in the future. Ambio 50, 726-727 (2021). https://doi-org.ezproxy.library.ubc.ca/10.1007/s13280-02001473-y

71. Lei, H. et al. The earthquake in Jiuzhaigou County of Northern Sichuan, China on August 8, 2017. Natural hazards, 90(2), 1021-1030(2018).

72. Sun, Y., \& Zhao, D. Environmental Campaigns. In Popular protest in China, 144-162(2009). Harvard University Press.

73. Jiang, Z. \& Xia, W. The niches of yaks, Tibetan sheep and plateau pikas in the alpine meadow ecosystem. Acta Biol. Plat. Sin. 6: 115-146(1987). 
74. Pech, R. P. et al. Population dynamics and responses to management of plateau pikas Ochotona curzoniae. Journal of Applied Ecology, 44(3), 615-624(2007).

75. Smith, A. T., \& Foggin, J. M. The plateau pika (Ochotona curzoniae) is a keystone species for biodiversity on the Tibetan plateau. Animal Conservation, 2(4), 235-240(1999).

76. Liu, J. Y., Xu, X., \& Shao, Q. Q. The spatial and temporal characteristics of grassland degradation in the three-river headwaters region in Qinghai Province. Acta Geographica Sinica, 4 (2008).

77. Sulek, E. R. Tibetan Word List. In Trading Caterpillar Fungus in Tibet, 297-304(2019). Amsterdam University Press.

78. Duflo, E. Women empowerment and economic development. Journal of Economic literature, 50(4), 1051-1079(2012).

79. Brooks, J., Waylen, K. A., \& Mulder, M. B. Assessing community-based conservation projects: a systematic review and multilevel analysis of attitudinal, behavioral, ecological, and economic outcomes. Environmental Evidence, 2(1), 1-34(2013).

80. Peng, F.W. "The Practice and Exploration on the Establishment of National Park System in China."International Journal of Geoheritage and Parks 6 (1): 1-16(2018). https://doi.org/10.17149/ijg.j.issn.2210.3382.2018.01.001.

81. Foggin, J.M., and Yuan, C. Promoting conservation and community development through ecotourism: Experiences from valued conservation landscapes on the Tibetan plateau. Plateau Perspectives Working Paper. Bishkek, Kyrgyzstan: Plateau Perspectives(2020). Available at http://plateauperspectives.org/downloads/

82. Li, W., \& Han, N. Ecotourism management in China's nature reserves. AMBIO: A Journal of the Human Environment, 30(1), 62-63(2001).

83. Linetti, L. "The Effect of Globalization on the Tourism Industry."Thrive Global, August 20, 2019.

84. Lybbert, T. J., \& Wydick, B. Poverty, aspirations, and the economics of hope. Economic Development and Cultural Change, 66(4), 709-753(2018).

85. Wang, G. et al. National park development in China: conservation or commercialization? Ambio, 41(3), 247-261 (2012).

86. Ma, T. et al. Tendencies of Residents in Sanjiangyuan National Park to the Optimization of Livelihoods and Conservation of the Natural Reserves. Sustainability, 12(12), 5173(2020).

87. Yan, W. China's First National Park, an Experiment in Living with Snow Leopards (2017).

88. Liu, Y. et al. China: The Tibetan Plateau, Sanjiangyuan Region Snow Leopards, 513-521 (2016): Elsevier.

89. Tamrat, M. et al. Human-wildlife conflict and coexistence: a case study from Senkele Swayne's Hartebeest Sanctuary in Ethiopia(2020). Wildlife Biology.

90. Palminteri, S. Hot stuff: improving chili fence effectiveness (in protecting crops from elephants) (2016). 


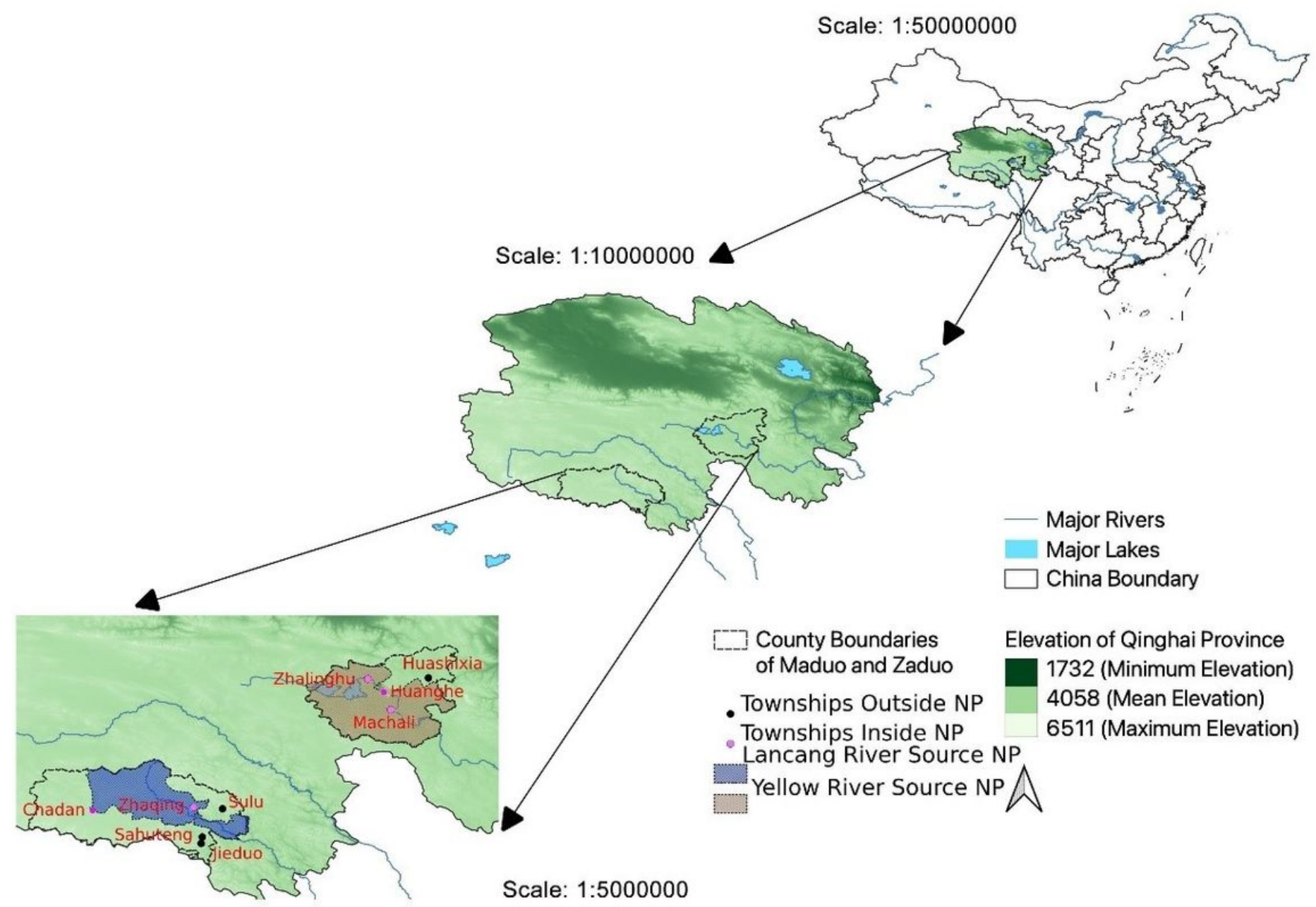

Figure 1

Study Sites of Sanjiangyuan Area 


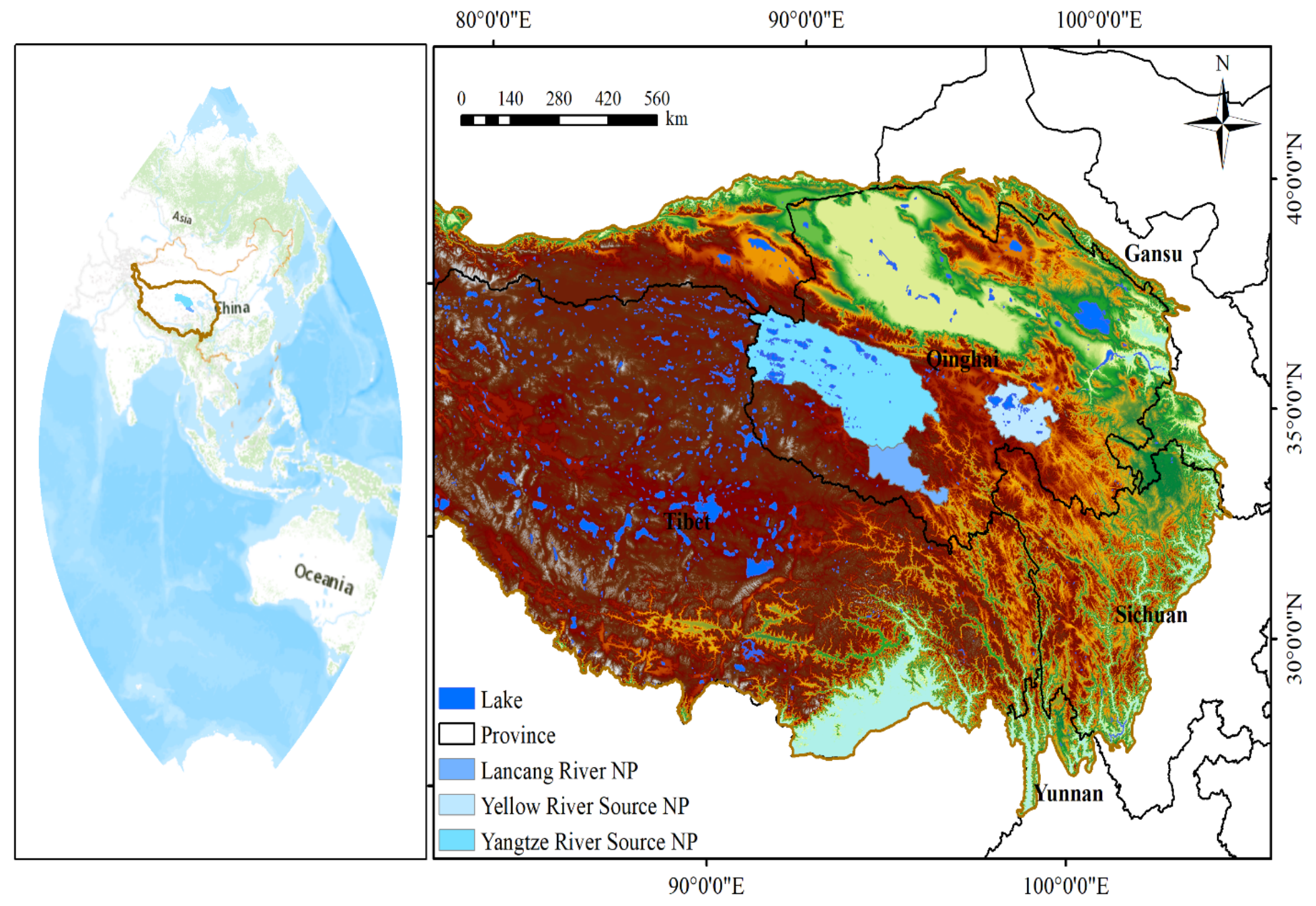

Figure 2

Map of the Tibetan Plateau and Sanjiangyuan National Park 